\title{
The Retention of the Employees as Long as Possible in the Organization, Through Finding the Right Factors of Motivation. Albania as a Case of Study
}

\author{
Sonela Stillo \\ Prof. As. Dr. University "Fan S. Noli”, Economic Faculty, Korca, Albania
}

Gentisa Furxhi

PhD Cand. , University “Fan S. Noli”, Economic Faculty, Korca, Albania

\begin{abstract}
One of the main objectives of an organization is the achievement of productivity, performance and high standards through the efficient use of the human resources and the application of the right technologies for combining the work force with the quantity of work. The job of the staff is done perfectly if you put the right person in the right position, in the right time. But to retain is more important than to employ. A talented employee will never run out of possibilities. The retention of employees is a process in which the employees are encouraged to stay in the organization for a maximal period of time. Even though the retention of the employees is a hard job for the organization, it is important for the organization as well as for the employee himself. If we assure the fulfillment of this important objective of the management of the human resources, thus the preservation of the human capacities, than we are in the right path of minimizing the turnover in the organization. For this to be possible it must be paid maximal attention to the employees, making them feel comfortable physically as well as psychologically in the workplace. Such thing requires the readiness of the organization to motivate the human resources. Exactly, the motivation of the employees is one of the most important factors that help the employer to improve the organizational and the employee's performance. The purpose of this study is evidencing the main factors that impact the level of motivation of the employees, their retention in the organization and a valuation of the rate of this impact.The data gathered from both public and private sector were analyzed through the software SPSS using the analyze of t-test, frequency, the pearson correlation, density.
\end{abstract}

Keywords: retention, employee, organization, strategy, career, performance.

\section{Introduction}

The pace of the economic development stresses the importance of the efficiency of the organizational operations. Nowadays, more and more organizational efficiency is conditioned by the effectiveness of the management of the human resources. The most effective and successful companies of nowadays apply successful methods of motivation, training, compensation and encouragement for their employees. This is a fact for all types of companies, manufacturing and service, big ones and small ones. Also in Albania, more and more private businesses and institutions of the public sector are paying a lot of attention in securing, developing and preserving a qualified work force. It is a positive thing that in the public sector is being applied the New Public Management, as the modern form of treating the management of the human resources. The need for a more specific treatment of the human resources is more visible nowadays with the change from the traditional management to the new management of the human resources, which means passing from the administrative function of the staff to that strategic; from a paternal style of management to a rational one; from the employment standardized practices to the flexible practices; from the role model of the employer to a new model of his role. ${ }^{1}$

Despite the indisputable importance of the human resources and their impact in the results of the organization, there is a place for the analyses which draw the issues of the way how these resources are treated and finding ways for the motivation

\footnotetext{
1 "Menaxhimi publik dhe efektiviteti i reformave ne sektorin public", Sonela Stillo, 2011
} 
of the employees. This will bring the improvement of the quality of the work life and the employees will feel as a social being that can grow and develop within the organization.

The issues addressed to the management of the human resources are different, but in our study we will focus in the need of finding the right motivators for the employees with the purpose to stimulate the retention of the staff as long as possible in the organization.

\section{Finding the right motivational factors for the retention of the employees in the organization; Albania as a case of study}

The retention of the employees is a process, in which the employees are encouraged to stay connected with the organization for a maximal period of time, preferably until they secede from the active work life. Even though this is a difficult process, it is necessary and helpful for the organization as well as for the employee himself.

The results are promising, if the department of the human resources employs from the beginning the right person, in the right position, in the right time. The staff of the human resources tries to carefully design and implement programs for the retention of the employees and through them it creates an environment that encourages and supports the employers to stay employed by holding strategies and practices that are addressed to their needs.

The programs for the retention of the employees are hard, because the retention is more important than the employment. Retention is often seen as connected with the turnover and with the costs regarding recruitment or training of the staff. Of course, this is true, but the need to retain employees is important to stop the fishing of the talented employees by the other companies. A talented employee will never run out of possibilities and with always be a target of the competitors.

When the talents leave, of course it is a disadvantage, but the negative effects are added when we think that with the human resource, the company also loses its information.

When an employee leaves, he takes away valuable information about the organization, the clients, the actual projects and also the history of the competition, and all this information goes to his new employer. A lot of time and money is spent for an employee who is expected to work in the future for the organization. So, when the employee leaves the organization, this investment fails.

There are various reasons that make the individuals leave their organizations. They can be personal or even professional. The employees never leave an organization without having a good reason. The most common reasons are: the person does not match with the job, there are no opportunities for growth, the absence of appreciation, the absence of trust, there is no support or coordination among the employees, bosses and managers, stress because of the overload and the imbalance of the job, the compensation strategies are not properly implemented, there is a new job offer, etc.

Or the nature of the work environment is such that the employees are faced with overload work, stressed bosses, absence of initiative and the fear of layoffs. These reasons have made many employees leave their actual organizations.

The tentative of the personnel staff must be in the direction of the growth of the will of the employees to stay as long as possible in the organization, but such thing requires the recognition of the motives that make these employees satisfied. If the management succeeds in ensuring the satisfaction and the happiness of the employees in the workplace, it obviously ensures their devotion in the job that will be reflected in the growth of the organizational indicators. This happens because a happy employee has a successful mix of professional and personal life.

To make such thing possible, must be carefully analyzed the environment where the human resource operates, in order to ensure a physical as well as a psychological wellbeing for every individual. This is a hard task of course, because the organization is responsible for applying the mechanisms as traditional as individual, because two people are never the same and the motives that push them towards stability, or leaving the organization depend on the individual perceptions. It is a duty and a responsibility of the department of the human resources to carefully analyze the human nature, to adapt everyone with the proper motivator. ${ }^{1}$

Nowadays when we talk more and more about the quality of the work life, it is required that the employees are treated with dignity from their employers.

\footnotetext{
1 "Managing Human Resources" Productovity, Quality of Work Life, Profit, Wayne F.Cascio, 2006 
A good employer should know how to attract and retain his employees. There must be many strategies to keep the employees comfortable in the actual job, but the strategy of motivation is the most effective. Inconsistent with the modern belief, the monetary compensation is not the highest motivator of the employees. According to the Harvard Management Update (June 1988), nine out of ten managers believe that people stay or leave because of the money. ${ }^{1}$ Money and benefits have an influence, but employees are more interested in a job that is challenging and meaningful, good bosses, opportunities to learn and development. ${ }^{2}$

From our survey, resulted that what makes the employees leave is the inconstancy of the individual with the job (70\%), without neglecting the lack of evaluation (21\%). Meanwhile, stress does not seem to be a factor for leaving the company because only $1 \%$ of the employees mentioned it. (Fig.2.1)

Our search was concentrated in both private and public sector. The subjects of the survey were the leaders as well as the employees. From the survey, $59 \%$ of the subjects were male and $41 \%$ female subjects. Our selection was random, but it also shows the problematic in the direction of the employment of women in Albania, especially in leading positions.

Regarding the age of the subjects, $3 \%$ were below the age of 20 years old, $55 \%$ from 21 to 30 years old, $28 \%$ from 21 to 40 years old and $6 \%$ over 50 years old.

Regarding the education, the major part (67\%) of the subjects had higher education, $22 \%$ had postgraduate education and only $11 \%$ had secondary education. For the employees in the business there is an increase in the average rate of the education, but we cannot say the same thing about the owners of the business. Despite this, the employment of a considerable number of specialists with higher education shows that the owners of the businesses know the rules of the market more than a decade ago, and they are becoming more and more conscious that the capacities of the educated human resources are essential to be successful in the competition that is open and more professional.

Regarding the years of work in the organization, we see that the majority of the participants $(59 \%)$ had less than 5 years employed, $32 \%$ had $5-10$ years, while only $9 \%$ had over 10 years employed.

But who is actually responsible for the retention of the employees? The answers given by the subjects of the survey were that the responsibility falls to the highest level (Fig 2.2). The retention of the employees starts from the top . To find, to employ and to retain good employees is the duty of the governing board. To find and to keep good staff requires concentrated policies and procedures, formal and informal that makes the retention of the employees a primary result of the management. The managers should evaluate the staff every day and should work constantly to keep them in the team.

Some of the main points of the study were the attempts to find the reasons that make the employees leave.

As seen in figure 2.3. the leaving reasons are mostly related with the under appreciation of the work done $(68 \%)$ and least related with the overtime work they are required to do (only $1 \%$ ). The limited work opportunities make the employees work overtime, even with no extra payment.

The turnover of the employees is not excluded from the costs. According to the data gathered from the survey, it results in a loss of the productivity (45\%) and loss of sales (25\%), while the recruitment cost is mentioned in only $13 \%$ of the cases and does not have the same impact as the two previous variables.

In $75 \%$ of the cases, the employees stay in the workplace because of the money and the benefits, $8 \%$ because of the challenging and meaningful job, $6 \%$ because of good bosses, $16 \%$ to develop and grow. So the personal interest of the employees is linked with the payment and the benefits, and the other dominating part is the experience and the opportunity for professional growth. (Fig 2.4)

We see that the payment plays a sensitive motivating role not only in the countries will low income as Albania, but also in other developed countries. What makes the difference is that in these countries, the material level achieved from the payment is sufficient for a normal life, and by taking this for granted, they aspire for the realization of higher ranking needs. Meanwhile in our country, the employees as well as the leaders aim for salaries that meet the material and security needs.

\footnotetext{
1 Harvard Management Update (June 1988)

2 Beverly Kaye and Sharon Jordan- Evans (2000)Retention:Tag, You're It!. Training and Development, April, pp: 29-34 
Therefore this is a very important factor and explains their behavior in the workplace and the degree in the independence of their judgment. ${ }^{1}$

The appliance of secret payment policies is a well known phenomenon and in $77 \%$ of the cases its use is accepted in the organization. While the ones that answered "yes" to the previous question (Tab 2.3), 71.4\% ( $n=55)$ of them thought that using the policy of the discreet payment brings distrust, $22.1 \%(n=17)$ thought that it reduces the motivation, $6.5 \%(n=5)$ thought that it reflects the organizational effectiveness.

Concerning the factors of the managerial aspect for the retention of the employees, it results that the programs of trainingdevelopment, the process of career planning, the growth opportunities, the high level of autonomy, the work ethics, challenging tasks in the workplace, the strong leadership, are valuated as important factors, while innovative factors are less important. The possible answers were ranked in Likert scale as following: very important, important, neutral, less important, not important at all. (Tab.2.4-2.11)

Orientation is an important function that influences the acceleration of the socialization process and the familiarization with the organization by reducing the will of the employees to leave. The major part of the organizations of the survey, use orientation programs for their employees. In $63 \%$ of the cases these are programs that last 1 week, but there are less ordinary cases in which they last 6 months $(1.6 \%)$ or even more $(6.3 \%)$. The major part of the subjects $(62 \%)$ does not assess the orientation process as efficient. The main reasons were fear in $35.5 \%$ of the cases and poor presentation in $33.9 \%$ of the cases.

An essential factor in the retention of the employees is the moral according to $87 \%$ of the subjects. The possible answers were in Likert scale and listed as follows: extremely, very much, on an average, a little, not at all. Moreover the impact of the moral in productivity and in customer service is considered as very important. The impact of the moral in the turnover is average, and it is absent in shortages or contention.

\section{Conclusions and recommendations}

The organization must treat its employees as a valuable asset of the company, and for this it should draft models of motivation and reward.

The organization should monitor the employees and constantly motivate them.

The management should develop evaluation criteria and instruments based on their abilities and performance.

The reward according to the performance valuates the individual and guarantees the success of the company.

The organization should retain and reward the individuals that perform beyond expectations.

There is no static strategy for the retention of the employees, but it should be in constant evolvement to retain and motivate the good employees.

The retention of the employees if favored by motivating them in an open communication that imposes the loyalty among them.

The program of the Career development is a valuable motivation for those individuals who think about expanding their activity and career.

The increase of the morale and the valuation of the employees has a very positive effect, even more than financial evaluation.

\section{References}

[1] Ahmet Ceni "Menaxhimi I shperblimit", 2007

[2] Beverly Kaye and Sharon Jordan- Evans (2000) Retention:Tag, You're It!. Training and Development, April, pp: 29-34

[3] Gülten Yurtseven "Importance of the Motivational Factors Affecting Employees Satisfaction", International Business

\footnotetext{
1 "Menaxhimi publik dhe efektiviteti i reformave ne sektorin public", Sonela Stillo, 2011
} 
Research Vol. 5, No. 1; January 2012

[4] Harvard Management Update (June 1988)

[5] KATHRYN MINSHEW," Four Employee Retention Strategies For The Modern Workplace", September, 23, 2015

[6] Sarah K. Yazinski, "Strategies for Retaining Employees and Minimizing Turnover", HR and Employment Law White Papers, August 03, 2009

[7] Sonela Stillo, "Menaxhimi I burimeve njerezore", 2011

[8] Sonela Stillo, "Menaxhimi publik dhe efektiviteti i reformave ne sektorin public", 2011

[9] Wayne F.Cascio, "Managing Human Resources" Productovity, Quality of Work Life, Profit, 2006

Tables

Table 2. 1 The descriptive statistics about the work years in the organization

\begin{tabular}{|l|l|l|l|l|l|}
\hline \multicolumn{2}{|c|}{} & Frequency & Percentage & Valuable Percentage & Acumulated Percentage \\
\hline \multirow{3}{*}{ Valid } & Less than 5 & 59 & 59.0 & 59.0 & 59.0 \\
\cline { 2 - 6 } & $5-10$ & 32 & 32.0 & 32.0 & 91.0 \\
\cline { 2 - 6 } & Over 10 & 9 & 9.0 & 9.0 & 100.0 \\
\cline { 2 - 6 } & Total & 100 & 100.0 & 100.0 & \\
\hline
\end{tabular}

Table 2. 2. The density according to the question "what is the cost of the turnover"

\begin{tabular}{|l|l|l|l|l|l|}
\hline \multicolumn{2}{|l|}{} & Frequency & Percentage & Valuable percentage & $\begin{array}{l}\text { Acumulated } \\
\text { percentage }\end{array}$ \\
\hline \multirow{3}{*}{ Valid } & The cost of recruitment & 13 & 13.0 & 13.0 & 13 \\
\cline { 2 - 6 } & The cost of training & 20 & 20.0 & 20.0 & 33 \\
\cline { 2 - 6 } & The cost of the loss of the productivity & 45 & 45.0 & 45.0 & 78 \\
\cline { 2 - 6 } & The cost of the loss of sales & 22 & 22.0 & 22.0 & 100.0 \\
\cline { 2 - 6 } & Total & 100 & 100.0 & & \\
\hline
\end{tabular}

Table 2. 3. The density according to the question "If yes, do you think it brings"

\begin{tabular}{|l|l|l|l|l|l|}
\hline \multicolumn{2}{|l|}{} & Frequency & Percentage & Valuable Percentage & $\begin{array}{l}\text { Acumulated } \\
\text { Percentage }\end{array}$ \\
\hline \multirow{3}{*}{ Valid } & Distrust & 55 & 71.4 & 71.4 & 71.4 \\
\cline { 2 - 6 } & Reduces motivation & 17 & 22.1 & 22.1 & 93.5 \\
\cline { 2 - 6 } & $\begin{array}{l}\text { Reflects organisational } \\
\text { effectiveness }\end{array}$ & 5 & 6.5 & 6.5 & 100.0 \\
\cline { 2 - 7 } & Total & 77 & 100.0 & 100.0 & \\
\hline
\end{tabular}

Table 2. 4. The densities according to "Programs of Training-Development"

\begin{tabular}{|l|l|l|l|l|l|}
\hline \multicolumn{2}{|c|}{} & Frequency & Percentage & Valuable Percentage & Acumulated Percentage \\
\hline \multirow{3}{*}{ Valid } & Very important & 39 & 39.0 & 39.0 & 39.0 \\
\cline { 2 - 6 } & Important & 56 & 56.0 & 56.0 & 95.0 \\
\cline { 2 - 6 } & Neutral & 4 & 4.0 & 4.0 & 99.0 \\
\cline { 2 - 6 } & Less important & 1 & 1.0 & 1.0 & 100.0 \\
\cline { 2 - 6 } & Total & 100 & 100.0 & 100.0 & \\
\hline
\end{tabular}

Table 2. 5 The densities according to "The process of career planning"

\begin{tabular}{|l|l|l|l|l|l|}
\hline \multicolumn{2}{|l|}{} & Frequency & Percentage & Valuable Percentage & Acumulated Percentage \\
\hline Valid & Very important & 22 & 22.0 & 22.0 & 22.0 \\
\hline
\end{tabular}




\begin{tabular}{|l|l|l|l|l|l|}
\hline & Important & 54 & 54.0 & 54.0 & 76.0 \\
\cline { 2 - 6 } & Neutral & 15 & 15.0 & 15.0 & 91.0 \\
\cline { 2 - 6 } & 8 & 8.0 & 8.0 & 99.0 \\
\cline { 2 - 6 } & Less important & & 1.0 & 1.0 & 100.0 \\
\cline { 2 - 6 } & Not important at all & 1 & 100.0 & 100.0 & \\
\cline { 2 - 5 } & Total & 100 & & \\
\hline
\end{tabular}

Table 2. 6. The densities according to "Growth opportunities"

\begin{tabular}{|l|l|l|l|l|l|}
\hline \multirow{2}{*}{ Valid } & Frequency & Percentage & Valuable Percentage & Acumulated Percentage \\
\cline { 2 - 6 } & Very important & 20 & 20.0 & 20.0 & 20.0 \\
\cline { 2 - 6 } & Important & 45 & 45.0 & 45.0 & 65.0 \\
\cline { 2 - 6 } & Neutral & 27 & 27.0 & 27.0 & 92.0 \\
\cline { 2 - 6 } & Less important & 7 & 7.0 & 7.0 & 99.0 \\
\cline { 2 - 6 } & Not important at all & 1 & 1.0 & 1.0 & 100.0 \\
\cline { 2 - 6 } & Total & 100 & 100.0 & 100.0 & \\
\hline
\end{tabular}

Table 2. 7. The densities according to "High autonomy level"

\begin{tabular}{|l|l|l|l|l|l|}
\hline \multicolumn{2}{|c|}{} & Frequency & Percentage & Valuable Percentage & Acumulated Percentage \\
\hline Valid & Very important & 18 & 18.0 & 18.0 & 18.0 \\
\cline { 2 - 6 } & Important & 35 & 35.0 & 35.0 & 53.0 \\
\cline { 2 - 6 } & Neutral & 35 & 35.0 & 35.0 & 88.0 \\
\cline { 2 - 6 } & Less important & 8 & 8.0 & 8.0 & 96.0 \\
\cline { 2 - 6 } & Not important at all & 4 & 4.0 & 4.0 & 100.0 \\
\cline { 2 - 6 } & Total & 100 & 100.0 & 100.0 & \\
\hline
\end{tabular}

Table 2. 8 The densities according to "Programs for innovative people"

\begin{tabular}{|c|l|l|l|l|l|}
\hline \multicolumn{2}{|c|}{} & Frequency & Percentage & Valuable Percentage & Acumulated Percentage \\
\hline Valid & Very important & 20 & 20.0 & 20.0 & 20.0 \\
\hline \multirow{5}{*}{} & Important & 17 & 17.0 & 17.0 & 37.0 \\
\cline { 2 - 6 } & Neutral & 23 & 23.0 & 23.0 & 60.0 \\
\cline { 2 - 6 } & Less important & 33 & 33.0 & 33.0 & 93.0 \\
\cline { 2 - 6 } & Not important at all & 7 & 7.0 & 7.0 & 100.0 \\
\cline { 2 - 6 } & Total & 100 & 100.0 & 100.0 & \\
\hline
\end{tabular}

Table 2. 9 The densities according to "Work ethics"

\begin{tabular}{|c|l|l|l|l|l|}
\hline \multicolumn{2}{|c|}{} & Frequency & Percentage & Valuable Percentage & Acumulated Percentage \\
\hline \multirow{3}{*}{ Valid } & Very important & 53 & 53.0 & 53.0 & 53.0 \\
\cline { 2 - 6 } & Important & 31 & 31.0 & 31.0 & 84.0 \\
\cline { 2 - 6 } & Neutral & 14 & 14.0 & 14.0 & 98.0 \\
\cline { 2 - 6 } & Less important & 1 & 1.0 & 1.0 & 99.0 \\
\cline { 2 - 6 } & Not important at all & 1 & 1.0 & 1.0 & 100.0 \\
\cline { 2 - 6 } & Total & 100 & 100.0 & 100.0 & \\
\hline
\end{tabular}

Table 2. 10 The densities according to "Challenging task at the workplace"

\begin{tabular}{|c|l|l|l|l|l|}
\hline \multicolumn{2}{|c|}{} & Frequency & Percentage & Valuable Percentage & Acumulated Percentage \\
\hline \multirow{2}{*}{ Valid } & Very important & 28 & 28.0 & 28.0 & 28.0 \\
\cline { 2 - 6 } & Important & 46 & 46.0 & 46.0 & 74.0 \\
\hline
\end{tabular}




\begin{tabular}{|l|l|l|l|l|l|}
\hline \multirow{4}{*}{} & Neutral & 19 & 19.0 & 19.0 & 93.0 \\
\cline { 2 - 6 } & Less important & 5 & 5.0 & 5.0 & 98.0 \\
\cline { 2 - 6 } & Not important at all & 2 & 2.0 & 2.0 & 100.0 \\
\cline { 2 - 6 } & Total & 100 & 100.0 & 100.0 & \\
\hline
\end{tabular}

Table 2.11 The densities according to "Strong leadership"

\begin{tabular}{|c|l|l|l|l|l|}
\hline \multicolumn{2}{|c|}{} & Frequency & Percentage & Valuable Percentage & Acumulated Percentage \\
\hline \multirow{3}{*}{ Valid } & Very important & 19 & 19.0 & 19.0 & 19.0 \\
\cline { 2 - 6 } & Important & 18 & 18.0 & 18.0 & 37.0 \\
\cline { 2 - 6 } & Neutral & 14 & 14.0 & 14.0 & 51.0 \\
\cline { 2 - 6 } & Less important & 30 & 30.0 & 30.0 & 81.0 \\
\cline { 2 - 6 } & Not important at all & 19 & 19.0 & 19.0 & 100.0 \\
\cline { 2 - 6 } & Total & 100 & 100.0 & 100.0 & \\
\hline
\end{tabular}

Figures:

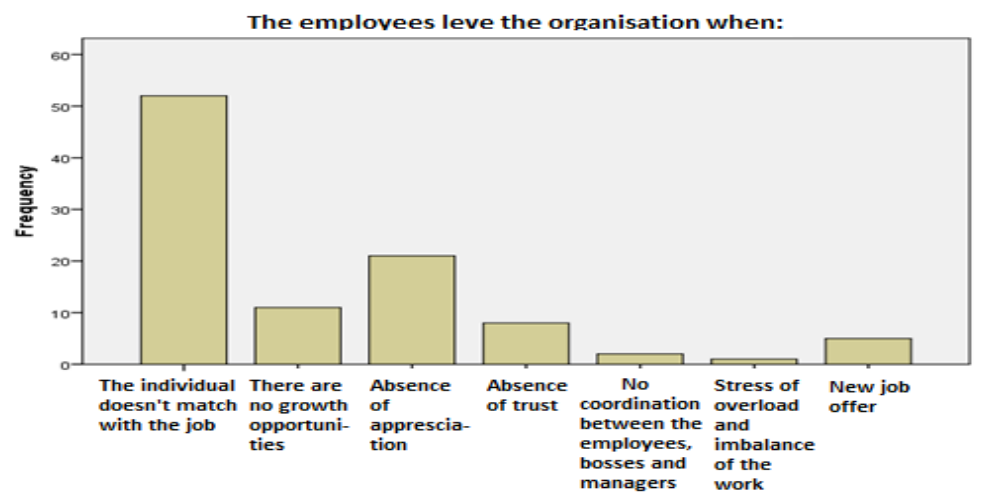

Fig. 2. 1 The reasons why the employees leave the organization

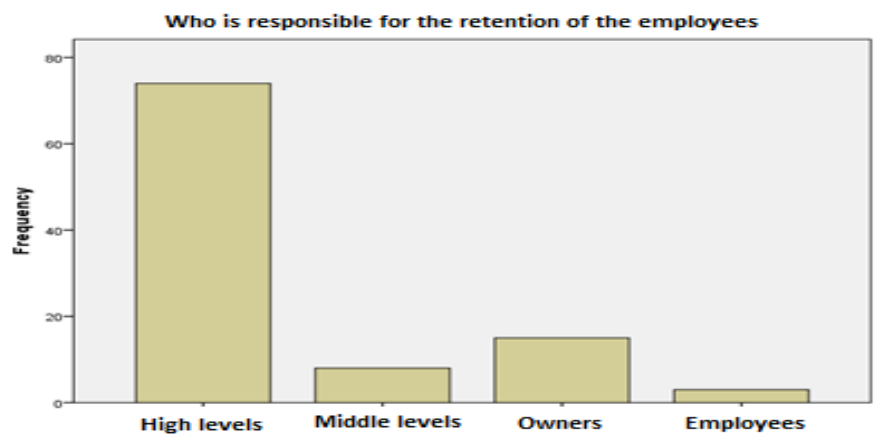

Fig. 2. 2. The responsible for the retention of the employees 


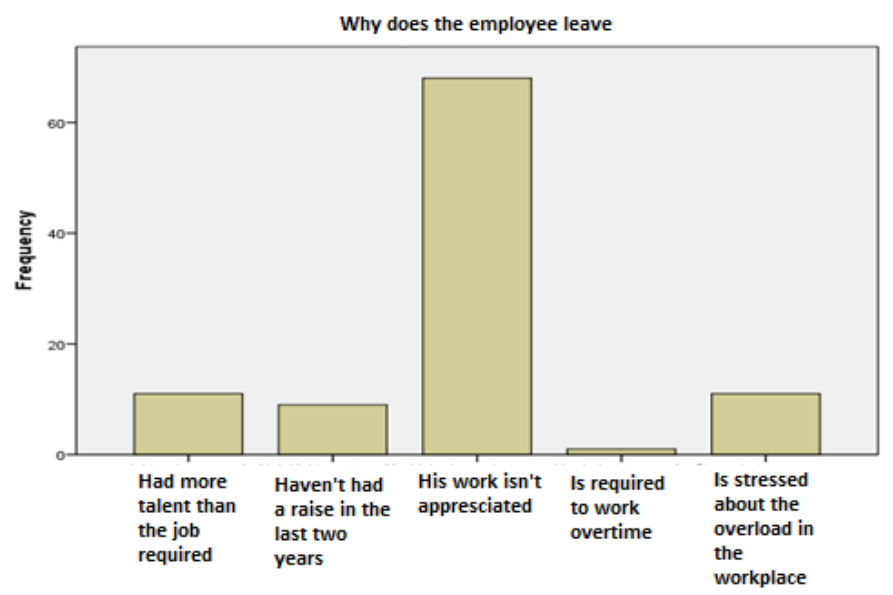

Fig 2. 3 The reasons the employees leave the organization

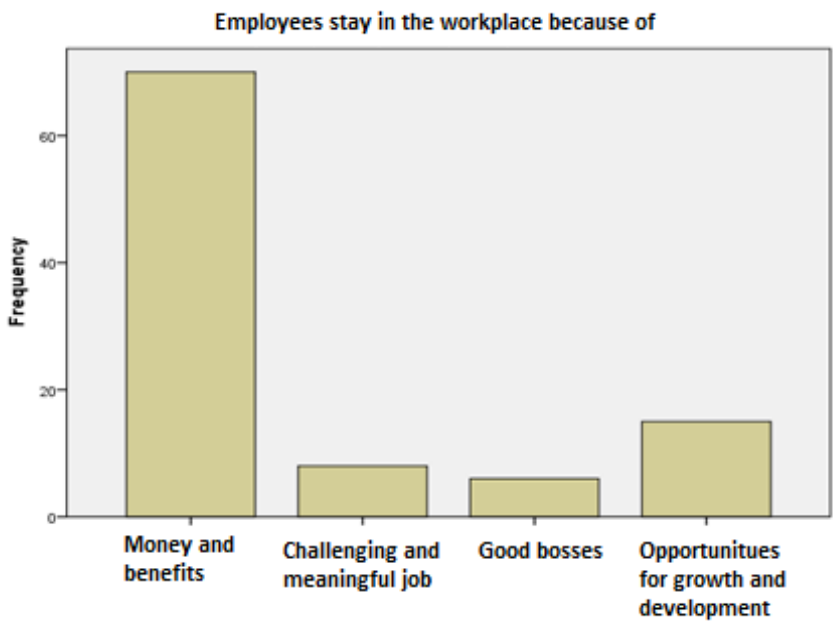

Fig 2. 4. The reasons employees stay at their job 